\title{
Optimasi Distribusi Lubang Pada Balok Baja Kastela
}

\author{
Windu Partono*, Sukamta, Siti Hardiyati, Listiyono Budi \\ Departemen Teknik Sipil, Fakultas Teknik, Universitas Diponegoro \\ Jl. Prof. Soedarto, SH, Kampus Undip Tembalang, Semarang, Indonesia 50275
}

\begin{abstract}
Abstrak
Balok baja kastela adalah profil baja yang dikembangkan dari profil I yang dipotong bagian badan dan disambung lagi sedemikian rupa sehingga membentuk lubang pada bagian badan. Bentuk lubang profil balok baja kastela pada umumnya adalah persegi enam (heksagonal). Pembuatan balok baja kastela perlu memperhatikan jarak antar lubang agar balok mempunyai kemampuan menahan beban tertinggi. Tulisan ini menyajikan hasil penelitian untuk menentukan jarak antar lubang yang optimum pada balok baja kastela dengan mempertimbangkan distribusi tegangan, deformasi, dan kelelehan pada balok tersebut. Penelitian diawali dengan perhitungan menggunakan metode Elemen Elemen Hingga (Finite Element Method /FEM) kemudian dilanjut dengan pengujian di laboratorium. FEM dilakukan untuk menentukan ukuran dan jarak antar lubang optimum pada balok kastela. Variasi sudut bukaan lubang dilakukan antara $45^{\circ}$ sampai $70^{\circ}$. Hasil analisa FEM kemudian diujikan di laboratorium dengan ukuran dan jarak antar lubang optimum untuk mengevaluasi perbedaan hasilnya. Hasil penelitian menunjukkan lubang profil dengan kemiringan antara $45^{\circ}$ sampai $70^{\circ}$ sebaiknya dibuat dengan jarak antar lubang antara 0.1 sampai 0.25 dari tinggi profil balok kastela dengan distribusi lubang terbaik adalah antara 5 sampai 7 lubang per meter.
\end{abstract}

Kata kunci: baja kastela; FEM; jarak lubang; ukuran lubang

\begin{abstract}
[Optimum Hole Distributions of Castellated Steel Beams] A castellated steel beam is a beam profile, customized from I-beam which subjected to a longitudinal cut along its web following a specific pattern and reassembled. The most common form of castellated steel beam hole is hexagonal. To maximize the strength, one must determine optimum hole size and distance between holes. This paper presents the result of research to determine optimum distance between holes by considering stress distribution, deformation, and yield stress. The research was begun by using Finite Element Method (FEM) then tested in laboratory. FEM was taken to determine the optimum distance between holes. The analysis was done by conducting $45^{\circ}$ to $70^{\circ}$ opening slope holes. FEM analysis results were then evaluated by performing laboratory test using the optimum distance between holes. The results showed that the castellated steel beams with $45^{\circ}$ to $70^{\circ}$ opening slope holes should be made with an approximate distance between holes is 0.1 to 0.25 of the castella profile height and the best hole distribution is 5 to 7 holes for each meter.
\end{abstract}

Keywords: castellated steel beam; FEM; hole distance; hole size

\section{Pendahuluan}

Balok baja kastela adalah profil baja yang dikembangkan dari profil I yang dipotong pada bagian badan dan disambung lagi sedemikian rupa sehingga membentuk lubang di bagian badan. Bentuk lubang profil

\footnotetext{
${ }^{*}$ Penulis Korespondensi.

E-mail: windu_bapake_dila@yahoo.com
}

balok baja kastela pada umumnya adalah persegi enam (heksagonal). Bentuk lubang lain yang juga sering digunakan adalah bentuk lubang lingkaran, walaupun bentuk ini jarang digunakan karena proses pembuatan yang lebih rumit dibandingkan bentuk heksagonal Secara umum proses pembuatan lubang heksagonal pada balok kastela dilakukan dengan urutan sebagaimana terlihat pada Gambar 1. Pada Gambar 1 terlihat ketinggian balok 


\section{TEKNIK, 39 (1), 2018, 2}

kastela "HK" lebih besar dibandingkan ketinggian balok asli "HI".

Hasil modifikasi balok asli menjadi balok kastela menghasilkan pembesaran luas penampang dan momen inersia tetapi memperkecil kekakuan dari penampang. Pembesaran penampang dan momen inersia akan meningkatkan kemampuan balok dalam menahan beban
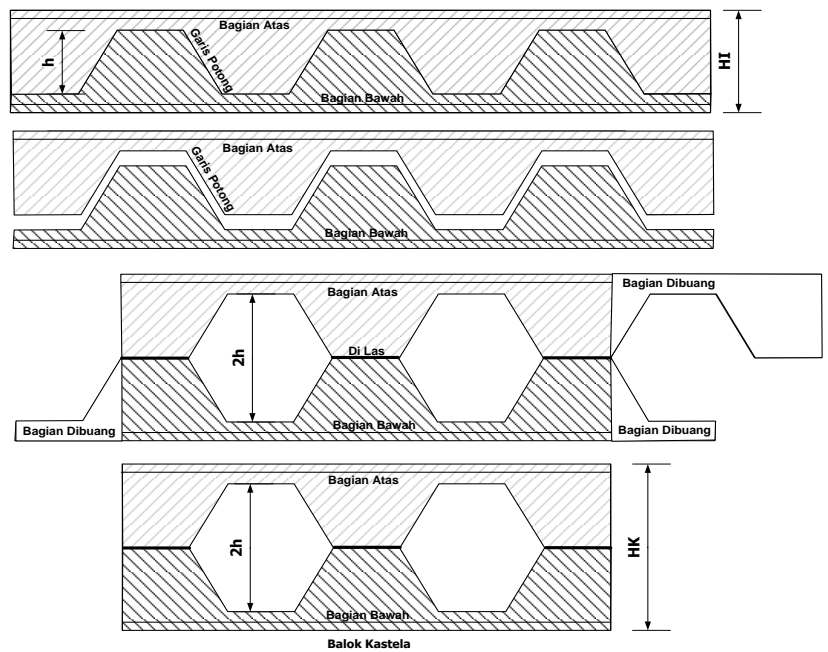

Gambar 1. Proses Pembuatan Balok Baja Kastela

yang bekerja padanya. Kekakuan penampang yang makin mengecil menyebabkan balok kastela rawan terhadap peristiwa buckling (Ellobody, 2011; Ellobody, 2012; Jichkar dkk., 2014, Zirakian \& Showkati, 2006). Potensi kegagalan yang sering terjadi pada balok kastela adalah pada bagian lubang atas (web atas), bawah (web bawah) dan pada bagian sambungan antara bagian atas dan bawah (Bedi \& Pachpor, 2011; Redwood \& Dermidjian 1998; Zaarour \& Redwood, 1996). Kekuatan las yang lebih tinggi dibandingkan kekuatan bagian badan pada umumnya akan mengurangi potensi kegagalan pada bagian sambungan las (Altfillisch dkk, 1957; Toprac \& Cooke, 1959).

Penentuan ukuran lubang, jarak antar lubang dan posisi lubang terhadap kedua sisi flange atas maupun bawah akan berpengaruh terhadap potensi timbulnya kerusakan lubang bagian atas dan bawah (Priyambodo dkk.., 2014; Wakchaure dkk., 2012). Persoalan yang sering dijumpai pada pengembangan profil balok kastela adalah penentuan ukuran lubang dan jarak antar lubang yang paling baik dalam mereduksi potensi kegagalan balok kastela (Apriyatno, 2000; Priyambodo dkk., 2014; Wakchaure dkk., 2012). Banyak ahli konstruksi yang kurang memahami cara penentuan ukuran lubang dan jarak antar lubang optimum yang dapat diterapkan dalam mengembangkan profil balok kastela. Tulisan ini menyajikan hasil penelitian yang dilakukan untuk menentukan ukuran lubang dan jarak antar lubang optimum yang dapat dikembangkan pada balok baja kastela. Penelitian dilakukan melalui dua tahap yaitu analisa model dengan bantuan komputer dengan menggunakan FEM untuk mendapatkan ukuran lubang dan jarak antar lubang optimum pada balok kastela (Jamadar \& Kumbhar, 2014; Khennane, 2013; Srimani \& Das, 1978; Suharjanto, 2004; Wakchaure \& Sagade, 2012). Data ukuran lubang maupun jarak lubang optimum yang diperoleh dari hasil analisa komputer kemudian diverifikasi dengan melakukan pengujian laboratorium untuk menguji seberapa besar perbedaan hasil analisa komputer dan hasil pengujian laboratorium (Darwin, 2003; Hosain \& Speirs, 1973)

\section{Bahan dan Metode}

Model yang digunakan pada penelitian ini adalah model lubang heksagonal. Model balok kastela dikembangkan dari model asli profil baja IWF 150.75.5.7. dengan tinggi profil $150 \mathrm{~mm}$, lebar flange $75 \mathrm{~mm}$. Hasil pengembangan profil asli menjadi profil kastela menghasilkan ukuran profil 225.75.5.7. Tinggi profil balok kastela adalah $225 \mathrm{~mm}$. Analisa model balok kastela untuk menentukan ukuran lubang dan jarak antar lubang dengan bantuan komputer dilakukan dengan menggunakan metode FEM. Ukuran lubang dan jarak antar lubang ditentukan dengan mengambil dua parameter "e" dan " $\phi$ " yang mencerminkan jarak antar lubang dan sudut kemiringan lubang (sudut bukaan lubang). Gambar 2 menunjukkan bentuk balok kastela dan ukuran lubang yang digunakan pada analisa dengan FEM. Tinggi lubang "HI" pada penelitian ini diambil sama dengan tinggi profil asli yaitu $150 \mathrm{~mm}$. Tinggi profil balok kastela "HK" adalah $225 \mathrm{~mm}$. Jarak pinggir lubang ke tepi profil "dt" adalah $37.5 \mathrm{~mm}$.

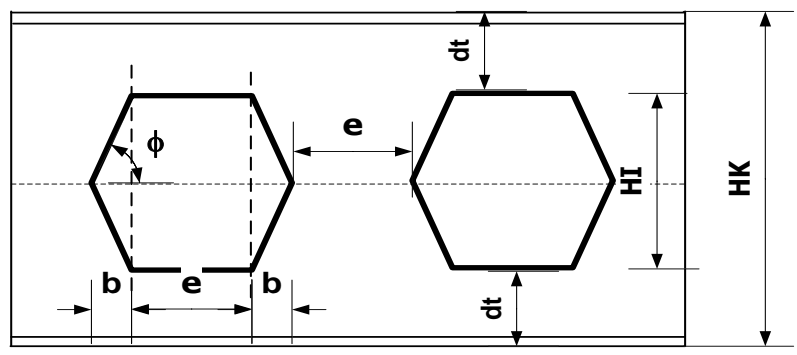

Gambar 2. Model Lubang Balok Kastela

Model struktur yang digunakan pada penelitian ini adalah model balok di atas dua tumpuan dengan dua beban terpusat (Wang, Ma \& Wang, 2014). Panjang balok ditentukan sebesar $3100 \mathrm{~mm}$ dengan jarak tepi balok ke sumbu tumpuan adalah $50 \mathrm{~mm}$ sehingga panjang bersih balok (jarak antara kedua tumpuan) pada model adalah $3000 \mathrm{~mm}$. Gambar 3 menunjukkan betuk model balok yang digunakan pada penelitian ini. 


\section{TEKNIK, 39 (1), 2018, 3}

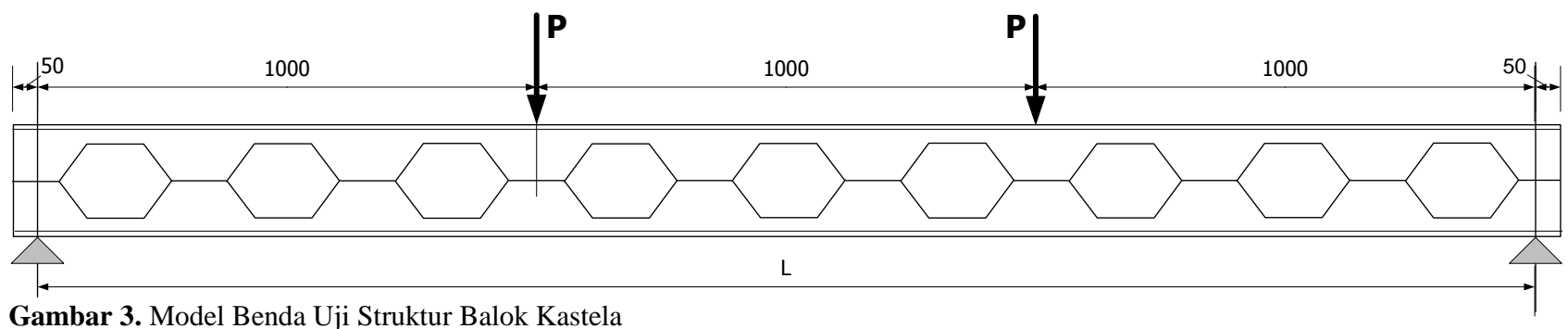

Pada Gambar 3 terlihat posisi setiap beban diambil sejarak $1000 \mathrm{~mm}$ terhadap posisi tumpuan. Optimasi bentuk lubang ditentukan dengan mengembangkan 6 model sudut kemiringan lubang " $\phi$ " masing-masing sebesar $45^{\circ}, 50^{\circ}, 55^{\circ}, 60^{\circ}, 65^{\circ}$ dan $70^{\circ}$. Variasi ukuran e untuk setiap nilai $\phi$ ditentukan berdasarkan panjang balok kastela "L", jumlah lubang per meter panjang benda uji "nl" dan sudut kemiringan $\phi$. Untuk menentukan jarak e dan jumlah lubang ditentukan dengan rumus pendekatan sebagaimana terlihat pada Persamaan 1. Jarak e ditentukan sedemikian rupa agar posisi beban $\mathrm{P}$ terletak pada bagian badan (web) dan tidak pada bagian lubang. Jumlah lubang untuk setiap meter panjang untuk setiap variasi sudut $\phi$ dapat dilihat pada Tabel 1. Jumlah lubang per meter panjang "nl" pada setiap sampel balok sebagaimana terlihat pada tabel tersebut detentukan dengan beda 3 . Sebagai contoh untuk model dengan sudut $\phi=45^{\circ}$ maka jumlah lubang per meter yang dipilih ada 6 masing-masing dengan jumlah lubang $3,6,9,12,15$ dan 18 .

$$
\mathrm{e}=\left[\frac{\mathrm{L}-\left(\mathrm{nl} * 2 * \frac{\mathrm{HI}}{2} \mathrm{tg} \phi\right)}{2 * \mathrm{n} 1}\right]
$$

Tabel 1. Nilai sudut $\phi$, jumlah sampel dan jumlah lubang $\mathrm{nl}$ yang dipilih pada analisa dengan FEM

\begin{tabular}{ccc}
\hline$\phi\left(^{\circ}\right)$ & Jumlah Sampel & nl \\
\hline 45 & 6 & $3-18$ \\
50 & 7 & $3-21$ \\
55 & 8 & $3-24$ \\
60 & 10 & $3-30$ \\
65 & 12 & $3-36$ \\
70 & 15 & $3-45$ \\
\hline
\end{tabular}

Analisa dengan FEM bertujuan untuk mendapatkan distribusi tegangan, nilai beban maksimum dan nilai defleksi maksimum sampai terjadinya leleh pertama. Analisa model komputer dilakukan dengan bantuan Software Abaqus ver 6.10 yang dikembangkan oleh Dassault System Simulia Corp. pada tahun 2010
(Khennane, 2013). Analisa FEM pada model balok Kastela dilakukan dengan pendekatan jumlah nodal 40000 dan ukuran mesh $5 \mathrm{~mm}$. Penentuan ukuran mesh pada analisa FEM dilakukan dengan metode konvergensi mesh dengan cara merubah ukuran mesh dari ukuran besar 25 mm sampai ukuran terkecil $4 \mathrm{~mm}$ sehingga diperoleh nilai defleksi dan tegangan Von Misses mencapai kenvergen. Model optimum yang diperoleh dengan FEM kemudian dilanjutkan dengan membuat model benda uji di laboratorium. Pengujian laboratorium bertujuan untuk memverifikasi model analisa yang dikembangkan dengan bantuan komputer. Jumlah benda uji yang dibuat di laboratorium sebanyak 3 buah masing-masing dengan panjang balok $3100 \mathrm{~mm}$ dengan jarak antar tumpuan 3000 $\mathrm{mm}$. Benda uji dibebani sampai terjadi kelelehan pertama. Sebelum dilakukan pengujian laboratorium maka dilakukan pengujian sampel baja yang diambil dari bagian flange dan web (Beer dkk., 2012; Craig, 2011; Gere \& Goodno, 2009; Pytel \& Kuisalaas, 2012; ). Sampel material baja ditest dengan pengujian tarik untuk mendapatkan nilai gield, altimate, aupture, modulus elastisitas (E), regangan material baja $(\varepsilon)$. Prosedur pengujian tarik baja sesuai dengan standar ASTM E 8M04 Standard Test Method for Tension Testing of Metallic Materials.

\section{Hasil dan Pembahasan}

Hasil pengujian material baja yang diambil pada bagian flange dan web dalam bentuk diagram teganganregangan dapat dilihat pada Gambar 4. Pada gambar terlihat nilai tegangan leleh dan tegangan putus pada bagian flange lebih besar dibandingkan dengan bagian web. Regangan yang diperoleh dari pengujian bagian flange lebih kecil dibandingkan dengan hasil pengujian pada bagian web. Dari hasil pengujian dan perhitungan rata-rata menunjukkan nilai oyield adalah $349.34 \mathrm{MPa}$, oultimate adalah $440.121 \mathrm{MPa}$ dan Modulus Elastisitas (E) adalah 211629.3656 MPa.

Data material hasil uji tarik sampel baja kemudian digunakan sebagai input untuk analisa komputer dengan menggunakan software Abaqus. Hasil analisa yang diperoleh dari program Abaqus meliputi data distribusi 


\section{TEKNIK, 39 (1), 2018, 4}

tegangan, nilai beban maksimum dan nilai defleksi maksimum.

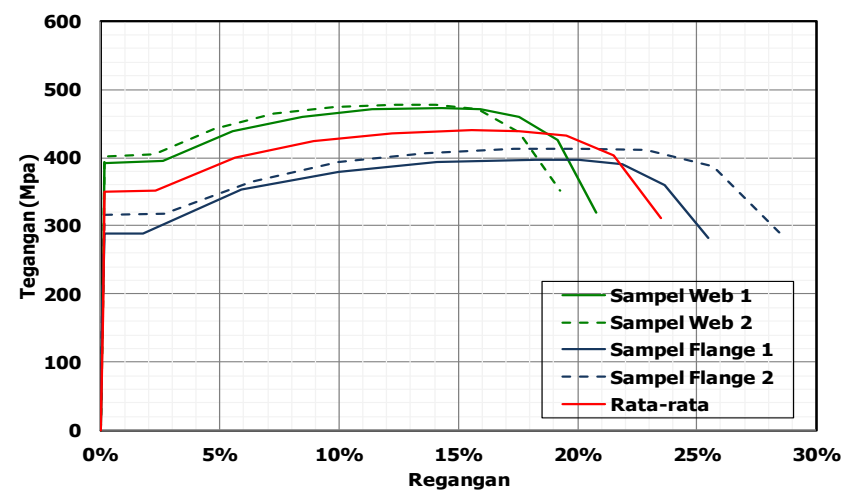

Gambar 4. Diagram Tegangan Regangan Material Baja

Proses analisa untuk masing-masing model balok baja kastela lubang heksagonal dilakukan sebanyak dua kali, yaitu analisa plastis hingga model mencapai leleh pertama dan analisa elastis dengan nilai beban maksimum $10 \mathrm{KN}$. Kedua proses analisa tersebut akan menghasilkan dua data yang berbeda, yaitu data distribusi tegangan, nilai beban maksimum dan nilai defleksi maksimum pada kondisi leleh pertama serta pada kondisi pembebanan mencapai $10 \mathrm{KN}$. Tabel 2 menunjukkan hasil analisa dengan menggunakan komputer dengan pendekatan elastis. Pada tabel tersebut terlihat hubungan atara sudut kemiringan $\phi$ dan jumlah lubang nl terhadap nilai $\mathrm{P}$ dan $\delta$ (deformasi vertikal) pada kondisi elastis. Nilai e dan $n l$ diambil berdasarkan nilai $\mathrm{P} / \delta$ tertinggi untuk setiap nilai $\phi$. Cara yang sama juga dilakukan pada kondisi leleh sebagaimana terlihat pada Tabel 3.

Jarak e pada Tabel 2 dan Tabel 3 merupakan jarak e yang diambil pada kondisi nilai $\mathrm{P} / \delta$ optimum. Nilai $\mathrm{P} / \delta$ optimum diperoleh dengan menggambarkan hubungan antara nilai $\mathrm{e} / \mathrm{HI}$ dan $\mathrm{P} / \delta$. Ukuran $\mathrm{HI}$ yang merupakan ukuran tinggi lubang diambil sebesar $150 \mathrm{~mm}$. Gambar 5 menunjukkan grafik hubungan antara $\mathrm{e} / \mathrm{HI}$ dan $\mathrm{P} / \delta$ untuk semua sampel dengan sudut bukaan $\phi$ antara $45^{\circ}$ sampai $70^{\circ}$. Nilai $\mathrm{P} / \delta$ sebagaimana terlihat pada Gambar 5 diperoleh dari hasil analisa semua sampel dalam kondisi elastis. Cara yang sama juga dilakukan pada kondisi leleh. Gambar 6 menunjukkan hubungan antara nilai e/HI dan $\mathrm{P} / \delta$ untuk semua sampel dengan sudut bukaan $\phi$ antara $45^{\circ}$ sampai $70^{\circ}$.

Dari semua grafik yang terlihat pada Gambar 5 maupun Gambar 6 terlihat sudut bukaan terbaik berkisar antara $45^{\circ}$ sampai $50^{\circ}$. Dari kedua gambar tersebut juga terlihat nilai e/HI terbaik berkisar antara 0.1 sampai 0.3 . Pada kondisi leleh sebagaimana terlihat pada Gambar 6 besar sudut bukaan $\phi$ terbaik berkisar antara $45^{\circ}$ sampai $50^{\circ}$. Nilai e/HI pada kondisi leleh tersebut berkisar antara 0.1 sampai 0.3 .

Pada Gambar 5 dan Gambar 6 terlihat nilai $\mathrm{P} / \delta$ pada kondisi optimum untuk kondisi elastis maupun leleh untuk semua nilai $\phi$ berkisar antara 6000 sampai 6500.

Tabel 2. Hasil Perhitungan $\mathrm{P}$ dan $\delta$ untuk Berbagai Variasi Sudut $\phi$ dan Jumlah Lubang nl pada Kondisi Elastis dengan Beban Maksimum $10 \mathrm{kN}$

\begin{tabular}{ccccc}
\hline \multirow{2}{*}{$\boldsymbol{\phi}\left({ }^{\mathbf{0}}\right)$} & $\mathbf{e}(\mathbf{m m})$ & $\mathbf{n l}$ & $\begin{array}{c}\mathbf{P} \\
\mathbf{n n N})\end{array}$ & $\begin{array}{c}\boldsymbol{\delta} \\
(\mathbf{m m})\end{array}$ \\
\hline 45 & 50,0000 & 4 & & 1,585 \\
& 25,0000 & 5 & & 1,572 \\
50 & 37,0000 & 5 & & 1,573 \\
& 20,3333 & 6 & & 1,582 \\
55 & 47,5000 & 5 & & 1,586 \\
& 30,8333 & 6 & 9,997 & 1,581 \\
60 & 39,8333 & 6 & & 1,594 \\
& 27,9286 & 7 & & 1,599 \\
65 & 48,8333 & 6 & & 1,618 \\
& 36,9286 & 7 & & 1,618 \\
70 & 56,3333 & 6 & & 1,646 \\
& 44,4286 & 7 & & 1,644 \\
\hline
\end{tabular}

Tabel 3. Hasil Perhitungan $\mathrm{P}$ dan $\delta$ untuk Berbagai Variasi Sudut $\phi$ dan Jumlah Lubang nl pada Kondisi Leleh

\begin{tabular}{ccccc}
\hline \multirow{2}{*}{$\boldsymbol{\phi}\left(\mathbf{(}^{\mathbf{}}\right)$} & $\mathbf{e}(\mathbf{m m})$ & $\mathbf{n l}$ & $\begin{array}{c}\mathbf{P} \\
(\mathbf{k N})\end{array}$ & $\begin{array}{c}\boldsymbol{\delta} \\
\mathbf{m m})\end{array}$ \\
\hline \multirow{2}{*}{45} & 50,0000 & 4 & 44,829 & 7,111 \\
& 25,0000 & 5 & 44,829 & 7,052 \\
50 & 37,0000 & 5 & 67,168 & 10,604 \\
& 20,3333 & 6 & 50,432 & 7,983 \\
55 & 47,5000 & 5 & 44,829 & 7,117 \\
& 30,8333 & 6 & 67,165 & 10,654 \\
60 & 39,8333 & 6 & 67,163 & 10,761 \\
& 27,9286 & 7 & 67,162 & 10,774 \\
65 & 48,8333 & 6 & 44,828 & 7,261 \\
& 36,9286 & 7 & 44,828 & 7,259 \\
70 & 56,3333 & 6 & 44,828 & 7,427 \\
& 44,4286 & 7 & 67,156 & 11,121 \\
\hline
\end{tabular}

Nilai $\mathrm{P} / \delta$ pada kedua kondisi tersebut hampir sama. Untuk menentukan nilai sudut bukaan $\phi$ dan jarak e optimum juga dilakukan dengan melihat peningkatan tegangan atau perbedaan antara tegangan leleh antara profil balok kastela dan balok asli (IWF 150.75.5.7). Gambar 7 menunjukkan grafik hubungan antara peningkatan tegangan dengan nilai e/HI pada kondisi leleh. Dari grafik sebagaimana terlihat pada tersebut nilai e/HI optimum terjadi pada saat peningkatan tegangan leleh antara profil balok kastela dan profil asli berkisar antara 1.98 sampai 2.034 atau terjadi peningkatan tegangan rata-rata sebesar $200 \%$. Kondisi ini terjadi pada semua sudut bukaan $\phi$. Nilai $\lambda$ pada Gambar 7 merupakan hasil perbandingan nilai $\mathrm{P} / \delta$ yang dihitung pada balok kastela dengan nilai 


\section{TEKNIK, 39 (1), 2018, 5}

$\mathrm{P} / \delta$ yang diperoleh pada balok asli. Pada Gambar 5 sampai Gambar 7 terlihat profil dengan sudut bukaan $\phi=$ $45^{\circ}$ merupakan profil dengan kemampuan menahan beban terbesar. Sedangkan profil dengan sudut bukaan $\phi=70^{\circ}$ merupakan profil dengan kemampuan menahan beban terkecil. Profil dengan sudut bukaan yang makin membesar mengalami perlemahan yang lebih besar dibandingkan profil dengan sudut bukaan yang lebih kecil.

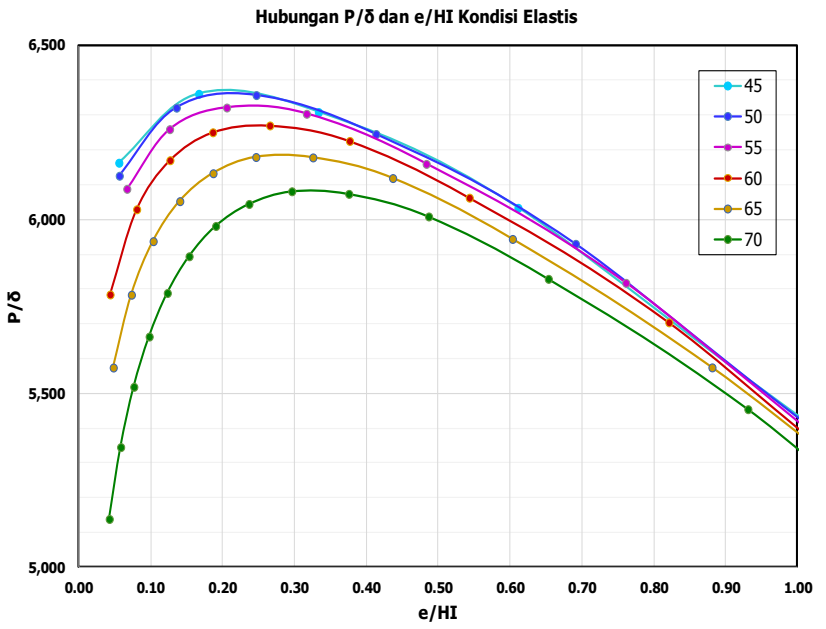

Gambar 5. Grafik Hubungan $\mathrm{P} / \delta$ dan $\mathrm{e} / \mathrm{HI}$ untuk semua sudut bukaan $\phi$ pada kondisi elastis

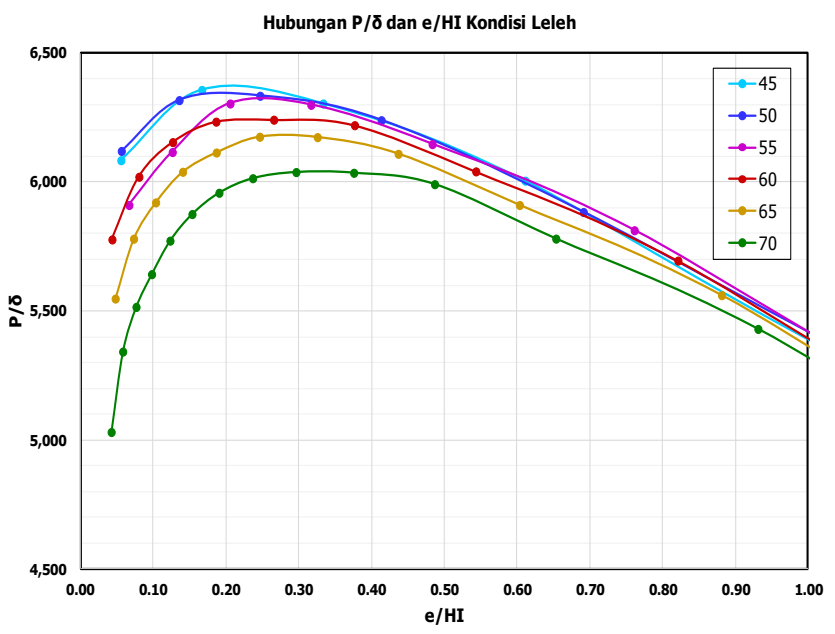

Gambar 6. Grafik Hubungan $\mathrm{P} / \delta$ dan e/HI untuk semua sudut bukaan $\phi$ pada kondisi leleh

Hasil analisa untuk menentukan jarak antar lubang dan bentuk ukuran lubang optimum menunjukkan setiap nilai $\phi$ menghasilkan satu jarak e optimum. Setiap sudut bukaan $\phi$ menghasilkan satu nilai optimum e/HI. Nilai e/HI optimum diperoleh pada kisaran angka 0.1 sampai 0.4. Jika menggunakan ukuran tinggi profil balok kastela HK, maka nilai e/HK optimum diperoleh diantara nilai
0.1 sampai 0.25 . Dengan menggunakan ukuran sampel balok sepanjang $3000 \mathrm{~mm}$ maka nilai e/HI dapat diperoleh dengan mengambil jumlah lubang antara 5 sampai 7 buah. Tabel 4 menunjukkan hubungan antara sudut bukaan $\phi$, jarak antara lubang e dan jumlah lubang nl yang diperoleh untuk sampel balok dengan panjang $3000 \mathrm{~mm}$. Jumlah lubang bukaan pada tabel tersebut diperoleh dari hasil perhitungan nilai $\mathrm{P} / \delta$ tertinggi.

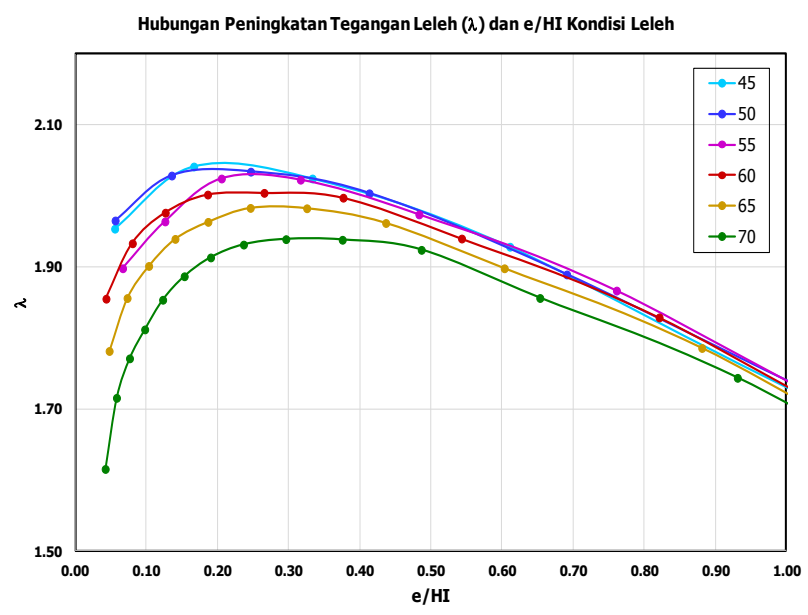

Gambar 7. Grafik Hubungan e/HI dan $\lambda$ untuk semua sudut bukaan $\phi$

Tabel 4. Hubungan Antara Jarak Lubang (e), Jumlah Lubang Setiap Meter dan Ukuran Lubang untuk Semua Nilai $\phi$

\begin{tabular}{ccccc}
\hline $\boldsymbol{\phi}\left(\mathbf{(}^{\mathbf{0}}\right)$ & $\mathbf{e}(\mathbf{m m})$ & $\mathbf{n l}$ & $\mathbf{e} / \mathbf{H I}$ & $\mathbf{e} / \mathbf{H K}$ \\
\hline 45 & 25,0000 & 5 & 0,167 & 0,111 \\
50 & 37,0000 & 5 & 0,180 & 0,164 \\
55 & 30,8333 & 6 & 0,226 & 0,137 \\
60 & 39,8333 & 6 & 0,266 & 0,177 \\
65 & 48,8333 & 6 & 0,326 & 0,217 \\
70 & 56,3333 & 7 & 0,376 & 0,250 \\
\hline
\end{tabular}

Hasil analisa dengan bantuan program Abaqus untuk selanjutnya diverifikasi dengan melakukan pengujian laboratorium untuk memastikan apakah model analisa dengan FEM sesuai dengan hasil pengujian laboratorium. Verifikasi yang dilakukan meliputi verifikasi defleksi dan beban maksimum pada saat leleh pertama. Berdasarkan hasil analisa sebagaimana terlihat pada Tabel 4 kemudian dipilih satu ukuran bukaan lubang $\phi$ untuk mendapatkan jarak antar lubang terbaik yang dapat digunakan sebagai sampel uji di laboratorium. Pada penelitian ini sampel ukuran bukaan yang dipilih adalah dengan sudut $\phi=70^{\circ}$ dengan jumlah lubang setiap meter panjang balok $\mathrm{nl}=7$. Gambar 8 menunjukkan detail ukuran lubang sampel balok kastela yang diuji di laboratorium (satuan ukuran dalam $\mathrm{mm}$ ) dan Gambar 9 


\section{TEKNIK, 39 (1), 2018, 6}

menunjukkan penyiapan pengujian balok kastela di laboratorium.

Berdasarkan hasil pengujian laboratorium yang dilakukan pada tiga sampel diperoleh grafik hubungan $\mathrm{P}$ dan defleksi vertikal $(\delta)$ sebagaimana terlihat pada Gambar 10. Beban maksimum pada ketiga sampel tersebut pada kondisi leleh pertama masing-masing adalah $75.021 \mathrm{kN}, 69.419 \mathrm{kN}$ dan $67.456 \mathrm{kN}$ dengan nilai $\delta$ masing-masing adalah $13.790 \mathrm{~mm}, 12.549 \mathrm{~mm}$ dan $12.629 \mathrm{~mm}$. Rata-rata P leleh dari ketiga sampel tersebut adalah $70.632 \mathrm{kN}$ dengan $\delta$ rata-rata $12.989 \mathrm{~mm}$.

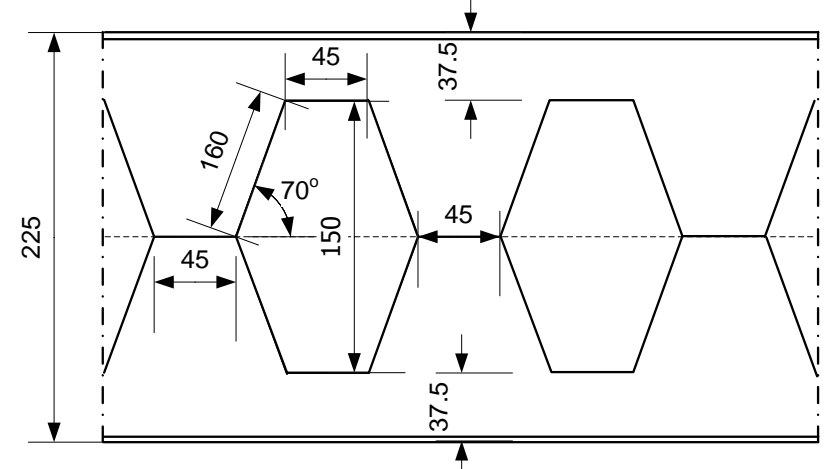

Gambar 8. Model Lubang untuk Sampel Uji

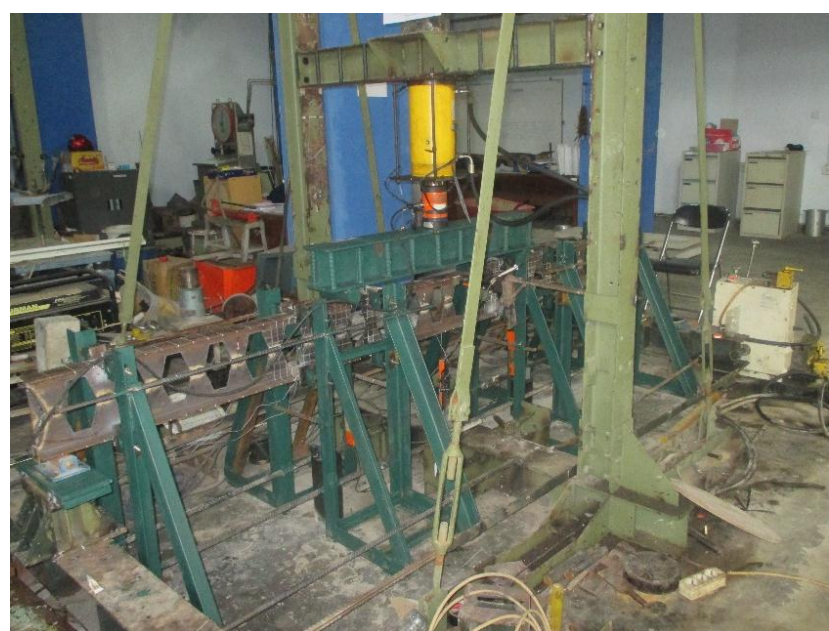

Gambar 9. Setting Pengujian Sampel Balok Kastela di Laboratorium

Analisa komputer untuk model benda uji laboratorium juga dilakukan untuk memverifikasi hasil pengujian laboratorium. Pada Gambar 11 juga ditampilkan hasil analisa untuk model yang sama dengan menggunakan komputer. Analisa dengan komputer tetap dilakukan karena adanya kemungkinan terjadinya perubahan dari ukuran lubang dan posisi lubang akibat kurang sempurnanya proses pembuatan benda uji laboratorium. Pembuatan model komputer juga dilakukan untuk tiga model. Pembuatan model komputer terhadap ketiga benda uji disebabkan kemungkinan adanya perbedaan ukuran balok baja kastela pada ketiga sampel balok di laboratorium. Hasil pengujian dengan menggunakan komputer menghasilkan nilai $\mathrm{P}$ rata-rata pada saat leleh pertama sebesar $69.182 \mathrm{kN}$ dengan defleksi vertikal rata-rata sebesar $12.373 \mathrm{~mm}$.

Hasil pengujian laboratorium kemudian dibandingkan dengan hasil analisa dengan komputer dan menghasilkan grafik hubungan $\mathrm{P}$ dan defleksi vertikal $(\delta)$ sebagaimana terlihat pada Gambar 12.

Grafik hubungan beban $(P)$ dan defleksi vertikal $(\delta)$ hasil pengujian laboratorium

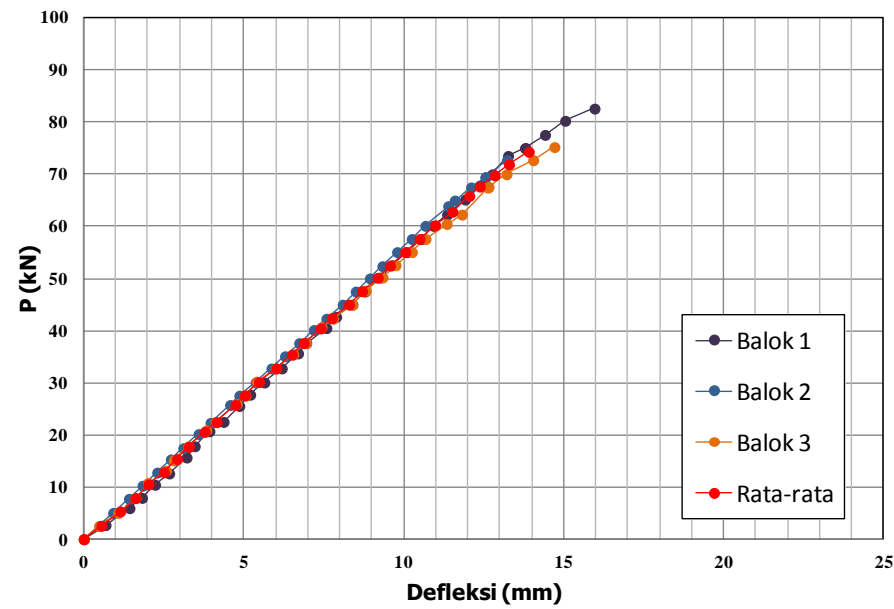

Gambar 10. Grafik Hubungan P dan Defleksi Vertikal Hasil Pengujian Laboratorium

Grafik hubungan beban ( $\mathrm{P})$ dan defleksi vertikal $(\delta)$ hasil analisa komputer

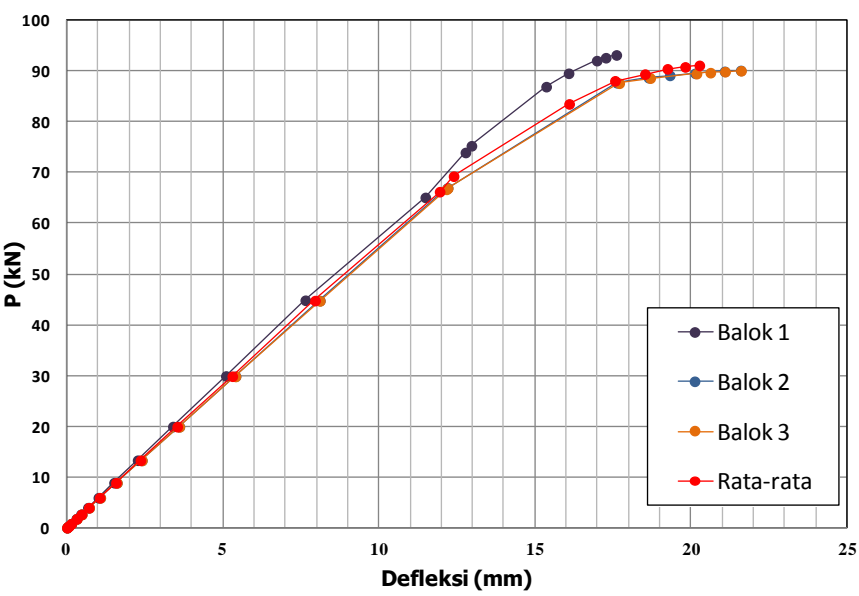

Gambar 11. Hasil Analisa Komputer

Pada gambar tersebut terlihat grafik hubungan antara P dan defleksi vertikal yang diperoleh dari pengujian laboratorium dan analisa komputer hampir sama atau hampir berimpit untuk nilai $\mathrm{P}$ kurang dari 68 $\mathrm{kN}$. Dari kedua grafik tersebut juga terlihat leleh pertama terjadi pada nilai $\mathrm{P}$ antara 68 sampai $70 \mathrm{kN}$. Grafik hubungan antara $\mathrm{P}$ dan defleksi vertikal hasil pengujian 


\section{TEKNIK, 39 (1), 2018, 7}

laboratorium maupun hasil analisa komputer sebagaimana terlihat pada gambar tersebut diambil dari nilai rata-rata hasil pengujian dari tiga sampel balok uji. Hasil pengujian laboratorium dan analisa komputer menunjukkan perbedaan nilai $\mathrm{P}$ maksimum hal ini disebabkan adanya ketidak sempurnaan pekerjaan pengelasan atau pembuatan profil balok uji. Meskipun demikian nilai $\mathrm{P}$ maksimum yang mencapai $70 \mathrm{kN}$ dari benda uji laboratorium menunjukkan kondisi leleh pertama yang hampir sama dengan hasil analisa model dengan komputer. Hal ini juga memberi gambaran bahwa pekerjaan pembuatan balok uji sudah sangat baik karena dapat menghasilkan P leleh yang hampir sama dengan hasil analisa komputer.

Grafik perbandingan hasil analisa dan pengujian laboratorium

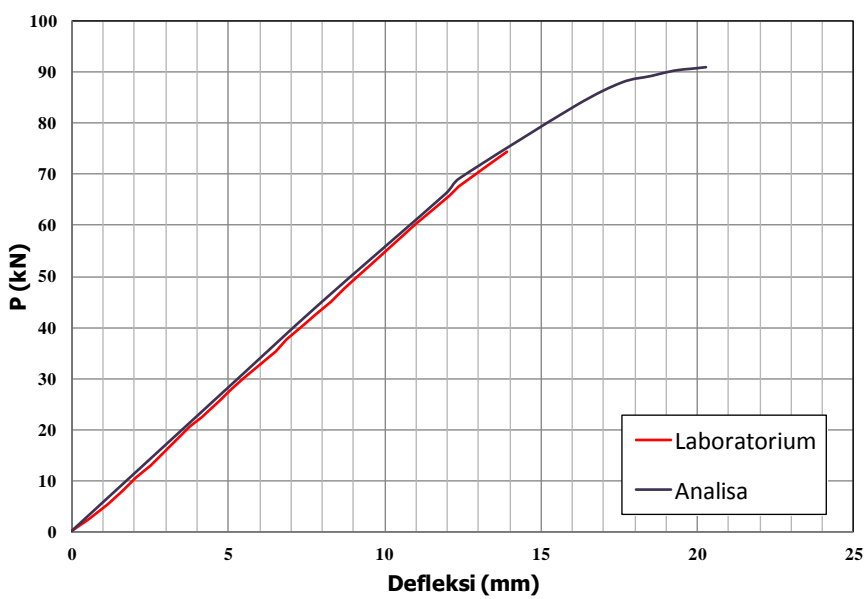

Gambar 12 Komparasi Hasil Pengujian Laboratorium dan Analisis Komputer untuk Model Balok Kastela dengan Sudut Bukaan $70^{\circ}$ dan Jarak Antar Lubang $45 \mathrm{~mm}$

\section{Kesimpulan}

Hasil penelitian untuk menentukan jarak lubang optimum pada profil balok baja kastela menunjukkan bahwa untuk model balok kastela dengan sudut bukaan antara $45^{\circ}$ sampai $70^{\circ}$ maka jarak lubang optimum adalah antara 0.1 sampai 0.4 dari tinggi profil asli atau antara 0.1 sampai 0.25 dari tinggi profil balok kastela, profil dengan sudut bukaan makin kecil menghasilkan kemampuan menahan beban lebih besar, dan pola distribusi lubang terbaik adalah antara 5 sampai 7 lubang setiap meter.

\section{Daftar Pustaka}

Altfillisch, M. D., Cooke, B. R., \& Toprac, A. A. (1957). An Investigation of Welded Open Web Expanded Beams, AWS Journal.

Apriyatno, H. (2000). Pengaruh Rasio Tinggi dan Tebal Badan Balok Castella pada Kapasitas Lentur. Tesis. Yogyakarta: Magister Teknik Sipil Universitas Gadjah Mada.
Bedi, M. K. S., \& Pachpor P. D. (2011). Moment and Shear Analysis of Beam with Different Web Openings. International Journal of Engineering Research and Applications (IJERA, 1(4), 19171921.

Beer, F. P., Johnston, E. R., DeWolf, J. T., \& Mazurek, D. F. (2012). Mechanics of Materials. Sixth Edition. New York: McGraw-Hill Companies.

Craig, R. R. (2011). Mechanics of Materials. Third Edition. New York: John Wiley and Sons.

Darwin, D. (2003). Design of Steel and Composite Beams with Web Openings. American Institute of Steel Construction (AISC)

Dassault Systems Simulia Corp (2010). Abaqus/CAE 6.10 User's Manuals. Dassault Systems Simulia Corporation.

Ellobody, E. (2011). Interaction of Buckling Modes in Castellated Steel Beams. Journal Construction Steel Research, 67, 814-825.

Ellobody, E. (2012). Nonlinier Analysis of Cellular Steel Beams under Combined Buckling Modes. ThinWalled Structures, 52, 66-79.

Gere, J. M., \& Goodno, B. J. (2009). Mechanics of Material. Seventh Edition, Toronto : Cengage Learning.

Hosain, M. U., \& Speirs, W. G. (1973). Experiments on Castellated Beams. Journal of the American Welding Society, Welding Res. Supp., 52(8), 329342.

Jamadar, A. M., \& Kumbhar, P. D. (2014). Finite Element Analysis of Castellated Beam: A Review. International Journal of Innovative Research in Advanced Engineering (IJIRAE), 1(9), 125-129.

Jichkar, R. R., Arukia, N. S., \& Pachpor, P. D. (2014). Analysis of Steel Veam with Web Openings Subjected to Buckling Load. International Journal of Engineering Research and Applications (IJERA), 4 (5), 185-188.

Khennane, A. (2013). Introduction to Finite Element Analysis Using Matlab and Abaqus, in Thin and Thick Plates. Boca Raton: CRC Press, Taylor and Francis Group.

Priyambodo, B., Suswanto, B., \& Kristijanto, H. (2014). Analisa Model Keruntuhan Variasi Bukaan Badan pada Profil Heksagonal Castellated Beam dengan Program FEA. Jurnal Teknik POMITS, 1(2), 1-6.

Pytel, A., \& Kuisalaas, J. (2012). Mechanics of Material, Second Edition. Stamford : Cengage Learning.

Redwood, R., \& Dermidjian, S., (1998). Castellated Beams Web Buckling in Shear. Journal of Stuctural Engineering, 124(10), 1202-1207.

Srimani, S. S. L., \& Das, P. K. (1978). Finite Element Analysis Castellated Beams. Computer and Structures, 9, 169-174. 


\section{TEKNIK, 39 (1), 2018, 8}

Suharjanto. (2004). Kajian Banding Secara Numerik Kapasitas dan Perilaku Balok Baja Kastela Menggunakan Program SAP 2000. Media Komunikasi Teknik Sipil, 13(2),114-121.

Toprac, A. A., \& Cooke, B. R. (1959). An Experimental Investigation of Open-Web Beams. Welding Research Council Bulletin Series, 47.

Wakchaure, M. R., \& Sagade, A. V. (2012). Finite Element Analysis of Castellated Steel Beam. International Journal of Engineering and Innovative Technology (IJEIT), 2(1), 356-370.

Wakchaure M. R., Sagade A. V., \& Auti V. A. (2012). Parametric Study of Castellated Beam with Varying Depth of Web Opening. International
Journal of Scientific and Research Publications, 2(8), 1-6.

Wang, P., Ma, N., \& Wang, X. (2014). Numerical Studies on Large Deflection Behaviors of Restrained Castellated Steel Beams in Fire. Journal Construction Steel Research, 100, 136-145.

Zaarour, W., \& Redwood, R. (1996). Web Buckling in Thin Webbeb Castellated Beams. Journal of Stuctural Engineering, 122(8), 860-866.

Zirakian, T., \& Showkati,H., (2006). Distortional Buckling of Castellated Beams. Journal Construction Steel Research, 62, 863-871. 